\title{
ENDOVASCULAR TREATMENT OF INTERNAL CAROTID ARTERY DISSECTION AND PSEUDOANEURYSM: CASE REPORT
}

\author{
Turgay DEMIR*, Mehmet BALAL*, Ahmet EVLİCE*, Şebnem BIÇAKÇI*, Erol AKGÜL** \\ *Çukurova University Faculty of Medicine, Department of Neurology, ADANA, TURKEY \\ **Çukurova University Faculty of Medicine, Department of Radiology, ADANA, TURKEY
}

\begin{abstract}
One of the rare causes of stroke in patients under 50 years of age is internal carotid artery (ICA) dissection based on trauma. Traumatic internal carotid artery dissections may be treated with anticoagulants, antiplatelets or endovascular approaches. Endovascular repair of traumatic ICA dissections has become more popular recently. Here we report the case of ICA dissection secondary to trauma treated with anticoagulants and endovascular approaches and during the followups with neurovascular imaging pseudoaneurysm was presented as a developed complication.
\end{abstract}

Key Words: Dissection, endovascular treatment, internal carotid artery, pseudoaneurysm, trauma.

\section{OLGU SUNUMU: İNTERNAL KAROTIS ARTER DISSKSIYYNUNUN ENDOVASKÜLER TEDAVİSİ VE PSÖDOANEVRIZMA}

\section{ÖZET}

Travmaya sekonder olarak gelişen internal karotis arter (İKA) diseksiyonu 50 yaș altındaki inmelerin nadir nedenlerindendir. Diseksiyonlar antikoagülan ilaçlar, antiplatelet ilaçlar, endovasküler yöntemlerle tedavi edilebilmektedir. Travmatik İKA diseksiyonlarının endovasküler yolla tedavisi son yıllarda yaygın olarak tercih edilen tedavi șeklidir. Bu yazıda travmaya sekonder olarak gelișen İKA diseksiyonunun endovasküler yöntemlerle ve antikoagülan ilaçlarla tedavi edilen, nörovasküler görüntüleme takipleri sırasında psödoanevrizma komplikasyonu gelişen bir olgu sunulmuştur.

Anahtar Sözcükler: Diseksiyon, endovasküler tedavi, internal karotis arter, psödoanevrizma, travma.

\section{INTRODUCTION}

Blunt or penetrating trauma of head and neck may lead to dissection of the cervical vertebral and carotid arteries, and later on pseudoaneurysm formation (1). The incidence of dissections of the internal carotid artery (ICA) after trauma ranges from 0.08 to $3.7 \%$ (2). Pseudoaneurysms can develop $20-40 \%$ of the cases (3).

Here, we report a case of ICA dissection secondary to trauma complicated by pseudoaneurysm who underwent endovascular treatment.

\section{CASE}

A 51-year-old man admitted to the emergency department with left-sided weakness and loss of consciousness. His family history was unremarkable, he had no history of systemic disease and drug use. He had no vascular risk factors. He had experienced a motor vehicle accident one day ago, resulting with a clavicular and rib fracture on the left side. The neurological examination on admission revealed lethargy, leftsided hemiplegia, neglect and Babinski sign on the left side. On admission Glasgow Coma Scale was 10

\footnotetext{
Corresponding author: Asst. Prof. Turgay Demir MD. Çukurova University Faculty of Medicine, Department of Neurology, Adana, Turkey.

Phone: +90 32233860 60-3206 E-mail: drtdemir@gmail.com

Received: $28.04 .2016 \quad$ Accepted: 25.08.2016

This article should be cited as following: Demir T, Balal M, Evlice A, Bıçakcı S, Akgül E. Endovascular treatment of internal carotid artery dissection and pesudoaneurysm: case report. Turkish Journal of Cerebrovascular Diseases 2017; 23 (1): 29-32. doi:10.5505/tbdhd.2017.28290
} 
(eye opening to verbal command, inappropriate verbal responses, motor response withdrawing from pain), National Institute Health stroke scale (NIHSS) was 12 and modified Rankin's scale (mRS) was 5.

Non-enhanced cranial Computerized Tomography (CT) was normal, there was not a dense artery sign on the right middle cerebral artery (MCA), however the diffusion-weighted imaging (DWI) gained one hour later after symptom onset revealed acute infarction in the territory of right upper division of MCA (Fig. IA). Laboratory tests revealed that renal and liver function tests, serum electrolytes were within normal limits. He was immediately transferred to the angiography suite and digital subtraction angiography (DSA) of the cranial vessels was performed. The time between onset of patient's complaints and groin puncture was 120 minutes; then, the time between groin puncture and occlusion access time was about five minutes. Procedure was as follows: through right femoral artery access with a 6-French introducer sheath and a 0.035-inch guidewire (Terumo Medical Corporation, Japan), an angiography of the aortic arch was performed through a Pigtail catheter. Selective angiography of the vertebral and carotid artery was carried out and the occlusion at the proximal part of the the right ICA was confirmed (Fig. IB). Anterior circulation flow was normal on the left side. Anterior communicating artery was patent and collateral flow was seen from the anterior and posterior cerebral artery to the territory of the right middle cerebral artery. Thrombus aspiration with 6-French Fargomax distal access catheter (Balt, Montmorency, France) was performed five times and partial recanalization was provided. An intimal flap was detected in the petrous segment afterwards and dissection in the petrous segment was diagnosed (Fig. IC). Occlusion and thrombus was seen in the proximal part of the M1 segment of right MCA. However, flow was present in distal part of MCA (Fig. IC). Occlusion in the MCA was passed through via the 0,016 microcatheter (Terumo Medical Corporation, Japan). Mechanical thrombectomy for the thrombus in the M1 segment of MCA were performed with a retrievable stent (Solitaire 4x20, ev3 Inc, Plymouth, MN), providing recanalization (Fig. ID).

The patient was put on anticoagulant therapy (1000 IU/h heparin) and dual antiplatelet (acetylsalicylic acid and clopidogrel) therapy following thrombectomy and stent implantation. The neurologic examination at the 24 th hour after stroke revealed left-sided hemiparesis (3/5) and still exisisting at the time of discharge. Two months later a $7 \times 13 \times 5 \mathrm{~mm}$ pseudoaneurysm in the cervical segment of the right ICA was observed on control CT angiography. DSA confirmed the pseudoaneurysm (Figure IE). A stent-graft (Direct Stent-Stent Graft, InSitu Technologies $®$, Inc., Minnesota, USA) was implanted into the right ICA covering the pseudoaneurysm. After the stent-graft implantation, there was no flow in the pseudoaneurysm (Figure IF). After six months, the neurologic examination revealed mild left-sided hemiparesis (4/5), mRS was 3 and NIHSS was 5.

\section{DISCUSSION}

Although the vast majority of the carotid artery dissections occur spontaneously, only $4 \%$ of the dissections are associated with severe trauma (4). The internal carotid artery dissection, as a cause of stroke, is infrequent yet significant, being responsible for $20 \%$ of ischemic strokes in patients under 50 years of age (5-8). The most common initial symptom of the craniocervical artery dissection is head and/or neck pain, found in 60$90 \%$ of patients $(9-13)$. Because of patient's unconscious mental status, we were unable to ask about head and neck pain to patient. Also we could not get any information from his relatives about head and neck pain. Head and neck pain may suggest underlying craniocervical artery dissection, particularly in young patients with stroke. Other manifestations of dissection are ischemic stroke, transient ischemic attack, Horner syndrome, lower cranial nerve palsy, subaracnoid hemorrhage $(9,14)$. Also an acute onset of the Horner syndrome within ischemic stroke and neck pain is meaningful for ipsilateral ICA dissection (13). In the present case the patient had a motor vehicle accident one day before stroke symptoms and did not have a Horner's syndrome. DSA is the gold standard for the diagnosis of the traumatic craniocervical arterial dissections. The DSA of the patient showed the occlusion of the right ICA and thrombus in the proximal part of MCA. Arterial dissection may cause ischemic stroke either by thromboembolism from the site of injury or as a result of hemodynamic insufficiency due to severe stenosis or occlusion. Although traumatic ICA dissection is a rare and serious cause of embolic stroke in young adults, life-threatening TICADs may be ignored (14). 

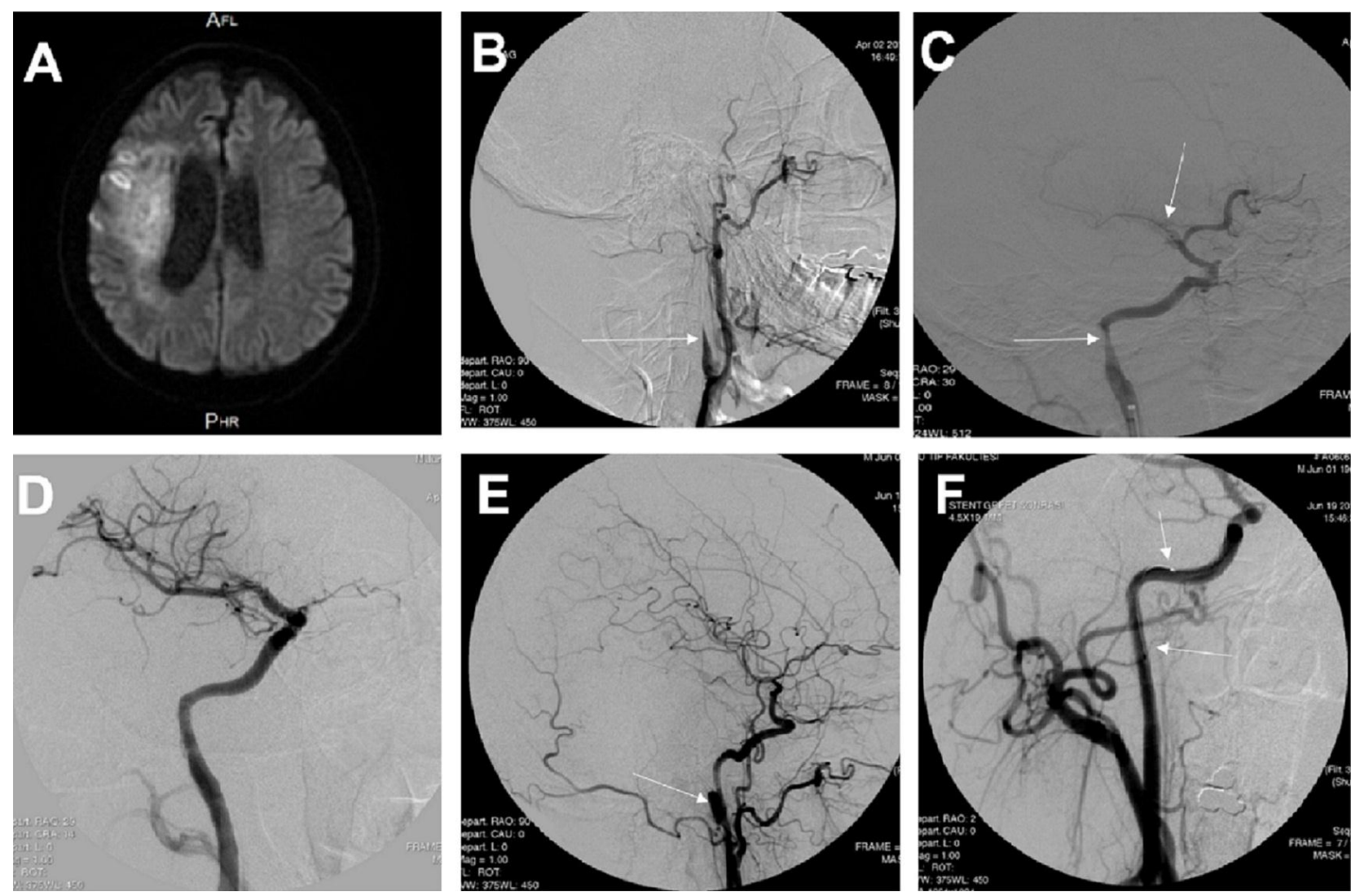

Figure IA. Acute infarction in the territory of middle cerebral arter (MCA) on DWI. B. Occlusion in the right internal carotid artery (ICA) has been shown. C. The filling defect in the distal cervical and proximal petrous segment of the right ICA, and the occlusion in the proximal of M1 segment of MCA have been shown. D. Recanalization was provided by thrombus aspiration in the proximal M1 segment of right MCA. E. Pseudoaneurysm at the right ICA. F. No flow was seen at the pseudoaneurysm following the stent-graft implantation, covering the pseudoaneurysm.

The prior repair of carotid artery and trauma are the most common causes of carotid pseudoaneurysms (15). The pathogenesis of pseudoaneurysms includes partial vessel injury and formation of a hematoma, whose unclotted portion is filled by circulating blood in continuity with the arterial lumen and is surrounded by a fibrous capsular wall (16).

Antithrombotic therapy either with systemic heparinization or antiplatelet agents has been associated with improved neurologic outcomes in patients with acute ischemic stroke secondary to dissection (16). According to the recent guidelines, antithrombotic or antiplatelet treatment is recommended in patients with neurological symptoms (Class IIa, Level B recommendation) and endovascular intervention is suggested only when neurological status of a patient deteriorates under conservative medical treatment (Class IIb, Level C recommendation) (16). As a popular treatment recently, endovascular approaches are minimally invasive methods for the treatment of dissections. In this case, we primarily performed endovascular treatment and then anticoagulant treatment. In many traumatic carotid dissection cases, primary treatment is using anticoagulant, though there may be a risk for intracranial and extracranial bleeding. Moreover, bleeding complication was not occurred in our patient. Patients with carotid artery dissections who failed medical therapy or presented with thromboembolic events and pseudoaneurysm are likely to require intervention undergo stent placement (18).

In traumatic internal carotid artery dissection cases, radiological follow-up should be done intermittently. Dissection is not a fixed situation however, recurrent lesions or the development of pseudoaneurysm may be seen (19). Thus, in our case, pseudoaneurysm was observed in CTA 
examination after 2 months of diagnosis and it was treated by endovascular approach.

In conclusion, the history of trauma should be questioned if a young stroke patient present with headache who do not have any vascular risk factors. Even in patients with total occlusion carotid artery dissections may be treated with endovascular approach. All the patients with craniocervical artery dissection should be followed up to 3-6 months intervals with neurovascular imaging for the development risk of pseudoaneurysm and recurrent dissections.

\section{REFERENCES}

1. Seth R, Obuchowski AM, Zoarski GH. Endovascular Repair of Traumatic Cervical Internal Carotid Artery Injuries: A Safe and Effective Treatment Option. Am J Neuroradiol. 2013 Jun-Jul;34(6):1219-1226.

2. Marschner-Preuth N, Warnecke T, Niederstadt TU et al. Juvenile stroke: cervical artery dissection in a patient after a polytrauma. Case Rep Neurol. 2013 Jan;5(1):21-25.

3. Diener HC, editor. Dissektionen hirnversorgender supraaortaler Arterien. Stuttgart: Georg Thieme Verlag; 2008. Leitlinien für Diagnostik und Therapie in der Neurologie.

4. Jansen G, Popp J, Dietrich U, et al. Traumatic dissection of the carotid artery: challenges for diagnostics and therapy illustrated by a case example. Der Anaesth. 2013;62(10):817-823.

5. Joseph T, Kandiyil N, Beale D, et al. A novel treatment for symptomatic carotid dissection. Postgrad Med J 2005;81:e6.

6. Baumgartner RW, Arnold M, Baumgartner I, et al. Carotid dissection with and without ischemic events: local symptoms and cerebral artery findings. Neurology 2001;57:827-832.

7. Benninger DH, Georgiadis D, Kremer C, et al. Mechanism of ischemic infarct in spontaneous carotid dissection. Stroke 2004;35:482-485.

8. Thanvi B, Munshi SK, Dawson SL, et al. Carotid and vertebral artery dissection syndromes. Postgrad Med J 2005;81:383-388.
9. Lee VH, Brown RD Jr, Mandrekar JN, et al. Incidence and outcome of cervical artery dissection: a population-based study. Neurology 2006; 67:1809.

10. Debette S, Grond-Ginsbach C, Bodenant M, et al. Differential features of carotid and vertebral artery dissections: the CADISP study. Neurology 2011; 77:1174.

11. Mokri B, Sundt TM Jr, Houser OW, et al. Spontaneous dissection of the cervical internal carotid artery. Ann Neurol 1986; 19:126.

12. Manabe $H$, Yonezawa $K$, Kato $T$, et al. Incidence of intracranial arterial dissection in non-emergency outpatients complaining of headache: preliminary investigation with MRI/MRA examinations. Acta Neurochir Suppl 2010; 107:41.

13. Debette $S$, Leys D. Cervical-artery dissections: predisposing factors, diagnosis, and outcome. Lancet Neurol 2009; 8:668.

14. Cogbill TH, Moore EE, Meissner M, et al. The spectrum of blunt injury to the carotid artery: a multicenter perspective. The Journal of Trauma-Injury Infection \& Critical Care. 1994;37(3):473-479.

15. El-Sabrout R, Cooley DA. Extracranial carotid artery aneurysms: Texas Heart Institute experience. Journal of Vascular Surgery 2000;31(4):702-712.

16. De Blasi R, Bracciolini E, Chiumarulo $L$, et al. Pseudoaneurysm formation following intrasphenoid rupture of an idiopathic intracavernous carotid artery aneurysm: Coil migration and early recurrence after endovascular treatment. Interv Neuroradiol. 2010; 16(4): 442-446.

17. Brott TG, Halperin JL, Abbara S, et al. 2011 ASA / ACCF / AHA / AANN / AANS / ACR / ASNR / CNS / SAIP / SCAI / SIR / SNIS / SVM / SVS guideline on the management of patients with extracranial carotid and vertebral artery disease: executive summary.Circulation. 2011;124:489532.

18. Moon K, Albuquerque F, Cole TS, et al. Endovascular Management of Cervical Carotid and Vertebral Artery Dissection: Indications, Techniques, and Outcomes From a 20-Year Experience. Neurosurgery. 2016 Aug; 63 Suppl $1: 205$.

19. Fabian TC, Patton JH, Croce MA, et al. Blunt carotid injury: importance of early diagnosis and anticoagulant therapy. Annals of Surgery. 1996;223(5):513-525. 